\title{
Antidiabetic effect of an aqueous extract of Pomegranate (Punica granatum L.) peels in normal and alloxan diabetic rats
}

\author{
Enas A. M. Khalil \\ National Organization For Drug Control \\ And Research
}

\begin{abstract}
Hypoglycaemic drugs are either too expensive or have undesirable side effects including hematological, coma and disturbances of liver and kidney.

Limiting of diabetes without any side effects is still a challenge to the medical system. This leads to exert effort to search for effective, safer and less cost antidiabetic plants.

This investigation aims to evaluate the role of Punica granatum powder peels extract in its human therapeutic dose on beta cell numbers blood glucose and plasma insulin levels in normal and alloxan diabetic rats for 4-weeks of treatment.

The treatment revealed that pomegranate aqueous extract significant decreased blood glucose and increased insulin levels in normal and diabetic treated rats. Pancreas showed increased number of beta cells in normal and treated diabetic rats.

In conclusion pomegranate peel aqueous extract can reduce blood sugar through regeneration of $\beta$ cells.
\end{abstract}

\section{Introduction}

It generally accepted that the sulphonyle ureas produce hypoglycemia in normal animals by stimulating the pancreatic $\beta$ cells to release more insulin .These drugs ,however, do not decrease blood glucose in alloxan diabetic animals (Goth,1985). In addition ,the exogenous administration of insulin is well known to produce hypoglycaemia in both normal and alloxan induced subjects (Larner,1985). This leads to increasing demand for natural products with potent antidiabetic and less side effect.

Various parts of Pomegranate (Punica granatum L.) have been used for various medicinal purposes .

Many studies have shown that the pomegranate peel extract has wound healing properties(Chidambara, et al, 2004), possesses antioxidant activity (Chidambara et al , 2002), immunomodulatory activity (Gracious et al, 2001), antibacterial activity (Prashanth et al, 2001), gastroprotectective effect (Gharzouli et al ,1999), larvicidal activity (Morsy et $a l, 1998$ ), antifungal activity (Dutta et al ., 1998), antitumor action (Mavhjanav et al, (1997), antimicrobial effect (Navarro, et al,1996), antiviral activity (Zhang et al,
1995) and hypoglycemia effect (Nogueira and Pereira, 1984, 1986 a,b; Zofar and Singh 1990).

It was found that Punica grantum peels contain tannins, anthocynins, flavonoids ,pectins (Nozire and Serpil,1993), three estrogen compounds luteolin, quercetin and kaempferol (Van-Elswijk et al, 2004).

This investigation aims to evaluate the role of Punica grantum powder peels extract in its human therapeutic dose on beta cell numbers, blood glucose and plasma insulin levels in normal and alloxan diabetic rats for 4-weeks of treatment

\section{Material and methods \\ Plant material}

$200 \mathrm{ml}$ boiling distilled water were added to3gm powder pomegranate peel, left it for 10 minutes and filtered .The filterate was dried at 40-45C0 in the incubator .

\section{Animals}

Male albino rats weighing $120 \pm 10 \mathrm{gm}$ were obtained from the observed first generation for a period of time. The animals were caged and provided with food and water adlibitum. Injection of alloxan 


\section{Enas A. M. Khalil}

monohydrate (Sigma USA), in a dose of $120 \mathrm{mg} / \mathrm{kg}$ B.wt. dissolved in acetate buffer immediately prepared before usage. Seven days after injection of alloxan blood glucose levels of all surviving rats were determined. Only rats with glucose levels above $200 \mathrm{mg} / \mathrm{ml}$ were considered diabetic and employed for the assay.

\section{Experimental design}

24 adult male albino rats weighing (110-130gm) were divided into four groups 6 rats each. Group I, represented control, group II diabetic rats, group III diabetic rats treated with $0.43 \mathrm{~g}$ of $\mathrm{P}$.granatum peel aqueous extract and group IV treated with $0.43 \mathrm{~g}$ of P. granatum peel extract, that dose equivalent to human therapeutic dose (Paget and Barnes, 1964) daily for 4 weeks.

\section{Blood sampling}

Blood samples were collected from retro-orbital vein in two separate tubes, one tube with EDTA for determination of hematological parameter. Red blood cells (RBCs) and (WBCs) were counted in Hemocytometer. The second tube containing potassium oxalate and sodium fluoride for estimation of glucose (Trinder, 1969)and insulin was estimated by kits obtained from IMX Abbott Labs/IL/USA.

Fresh pancreas samples were collected in formal saline,stained in $\mathrm{H} \& \mathrm{E}$ Some section of pancreas were stained by modified aldehyde fuchsine (M.A.F.) (Kiernan, 1999).

\section{Statistical analysis}

All data obtained were analyzed using student ' $\mathrm{t}$ ' test according to (Sendecor and Coebram,1969)

\section{Results and Discussion}

Preliminary studies showed that $\mathrm{P}$. granatum rind extract possessed significant blood sugar lowering activity. (Nogueira and Pereira,1984, 1986a,b\&Zafar and Singh, 1990)

Nougueira and Pereira, 1986b attributed, the antihyperglycaemic action of the peel extract of $\mathrm{P}$. granatum, to the inhibitory intestinal absorption of glucose in rats .

This investigation aims to evaluate the role of Punica grantum powder peel aqueous extract in its human therapeutic dose on beta cell numbers, blood glucose and plasma insulin levels in alloxan diabetic rats for 4-weeks of treatment As well as to illustrate the mechanism of hypoglycaemic effect of the extract

There was a significant weight loss in diabetic rats (table1), (fig.1), while in diabetic group treated with $\mathrm{P}$. granatum aqueous peel extract, an improvement in their body weights was observed. The ability of pomegranate rind extract to prevent body weight loss seems to be due to its antidiabetic activity. Pomegranate peel extract treated normal rats resulted in nonsignificant increase in body weight after4weeks.

The red blood cells(table1,fig.2) and haemoglobin decreased significantly in diabetic rats (table1,fig.4). WBCs showed non-significant change at 30 days by alloxan treatment (table1,fig.3) Diabetic rats treated with pomegranate peel extract displayed non-significant alternation in the red blood cells, haemoglobin and white blood cells from their corresponding control .In rats treated with pomegranate peel extract ,the red blood cells and haemoglobin increased significantly as the result of pomegranate peel haemostatic property (Machado et al, 2002) while WBCs displayed non-significant variation comparable to control for 4-weeks.

(Table1, fig.5) displayed significant elevation in plasma glucose and significant reduction in insulin level in diabetic rats (table1,fig.6). Pancreas showed reduction in $\beta$ cell numbers, $\beta$ cells necrosis and intracellular vacuolation (fig8) compared to control (fig.7). Diabetic rats treated with $0.43 \mathrm{~g} / \mathrm{KgB}$.W. of Punica granatum aqueous peel extract for 4 weeks displayed significantly lowered blood sugar level (table1, fig 5) and augmentation in insulin level(table $1 \&$ fig. 6$)$. The number of $\beta$ cells relatively increased, while vacuolation still appeared in some cells (fig.10). Punica granatum aqueous peel extract significantly lowered blood sugar and increased insulin 
level (table1 \& figs. 8, 9) and the number of $\beta$ cells increased (fig.10) Alloxan has shown to induce free radical production and cause tissue energy (Hallwell and Gutteridge, 1985). The pancrease is especially susceptible to the action of alloxan -induced free radical damage. Punica grantum aqueous peel extract possesses strong antioxidant property (Chidambara $e t$ $a l, 2002)$ can act as free radical scavenger and protect $B$ cells from damage .

Plant extract treated normal rats revealed significant reduction in blood sugar and elevation in insulin level. The number of $B$ cells increased.

The mechanism of the antidiabetic activity shown by the extract is protection of pancreas, stimulation of $\beta$ cells, increase number of $\beta$ cells and subsequent release of insulin. Also it may increase insulin receptor.

In conclusion pomegranate peel aqueous extract can reduce blood sugar through regeneration of $\beta$ cells.

Table (1): Showing the effect of treatment with $0.43 \mathrm{~g} / \mathrm{kgBW}$ Pomegranate(Punica granatum) peel aqueous extract for 4 weeks in body weights, some haematological parameters, blood glucose and insulin in normal and diabetic rats.

\begin{tabular}{|c|c|c|c|c|}
\hline Parameters & Control & Diabetic & $\begin{array}{c}\text { Diabetic treated } \\
\text { with Pomegranate }\end{array}$ & $\begin{array}{c}\text { Normal } \\
\text { treated with } \\
\text { Pomegranate }\end{array}$ \\
\hline $\begin{array}{l}\text { Body weight } \\
\text { (gm) }\end{array}$ & $\begin{array}{c}145.83 \\
\pm 4.92\end{array}$ & $\begin{array}{c}123.33^{*} \downarrow \\
\pm 6.83\end{array}$ & $\begin{array}{c}130 \\
5 \pm\end{array}$ & $\begin{array}{r}140 \\
\pm 3.5\end{array}$ \\
\hline $\begin{array}{l}\mathrm{R} \mathrm{BCs} \\
\times 10^{6}\end{array}$ & $\begin{array}{c}5.35 \\
\pm 0.66\end{array}$ & $\begin{array}{c}2.25 * \downarrow \\
\pm 2\end{array}$ & $\begin{array}{c}5.5 \\
\pm 0.5\end{array}$ & $\begin{array}{c}7.5 \times 10^{6} \\
\pm 1\end{array}$ \\
\hline $\begin{array}{l}\text { W B Cs } \\
\times 10^{3} \\
\end{array}$ & $\begin{array}{l}4.66 \\
\pm 0.6 \\
\end{array}$ & $\begin{array}{l}6.76 \\
\pm 0.8 \\
\end{array}$ & $\begin{array}{r}7 \\
\pm 1 \\
\end{array}$ & $\begin{array}{c}8 \\
\pm 2 \\
\end{array}$ \\
\hline $\begin{array}{l}\mathrm{Hb} \\
(\mathrm{gm} \%)\end{array}$ & $\begin{array}{c}16.33 \\
\pm 1 \\
\end{array}$ & $\begin{array}{c}12.5^{*} \downarrow \\
\pm 0.8 \\
\end{array}$ & $\begin{array}{r}16.5 \\
\pm 0.5 \\
\end{array}$ & $\begin{array}{l}18 \\
\pm 1 \\
\end{array}$ \\
\hline $\begin{array}{l}\text { Glucose } \\
(\mathrm{mg} / \mathrm{dl})\end{array}$ & $\begin{array}{l}85 \\
\pm 2\end{array}$ & $\begin{array}{c}280^{* \uparrow} \\
\pm 5\end{array}$ & $\begin{array}{c}120^{* \uparrow} \\
\pm 10\end{array}$ & $\begin{array}{l}75^{*} \downarrow \\
\pm 2.5\end{array}$ \\
\hline $\begin{array}{l}\text { Insulin } \\
(\mu \mathrm{U} / \mathrm{ml})\end{array}$ & $\begin{array}{l}12.5 \\
\pm 0.5\end{array}$ & $\begin{array}{l}7.5^{*} \downarrow \\
\pm 0.8\end{array}$ & $\begin{array}{c}12 \\
\pm 0.5\end{array}$ & $\begin{array}{c}15 * \uparrow \\
\pm 1\end{array}$ \\
\hline
\end{tabular}

Number of rats in each group $=6$

$\mathrm{P}<0.05$ compared with control group

Fig1: Showing the effect of treatment wiak3g/kgBW Pomegran at(Punica granaturimpeel aqueous extract for 4 weeks in body weights in normal and diabetic rats

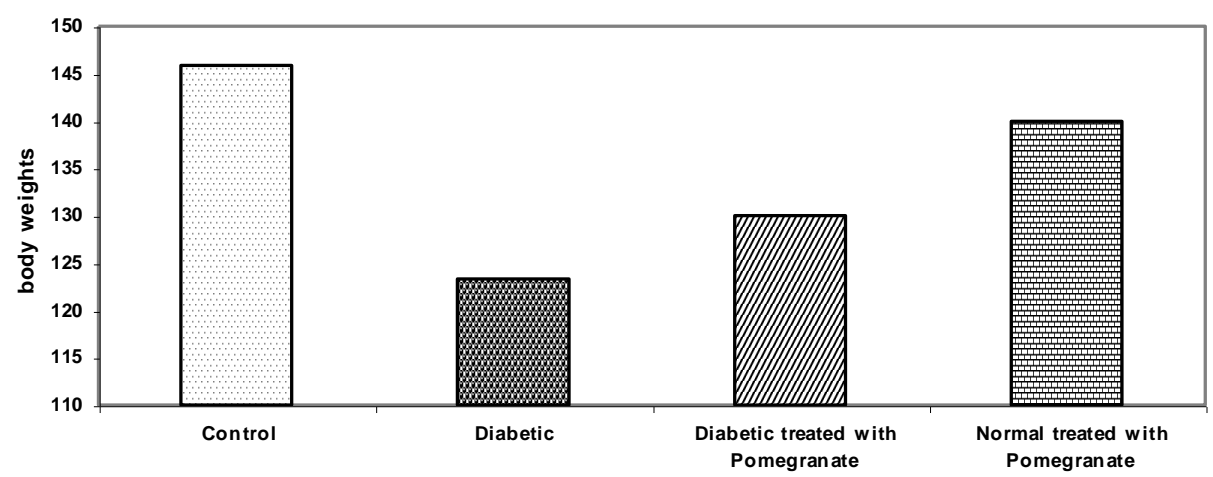


Enas A. M. Khalil

Fig 2: Showing the effect of treatment with $0.43 \mathrm{~g} / \mathrm{kgBW}$ Pomegranate (Punica granatum) peelaqueous extract for 4 weeks in R BCs $\times 10^{6}$ in normaland diabetic rats

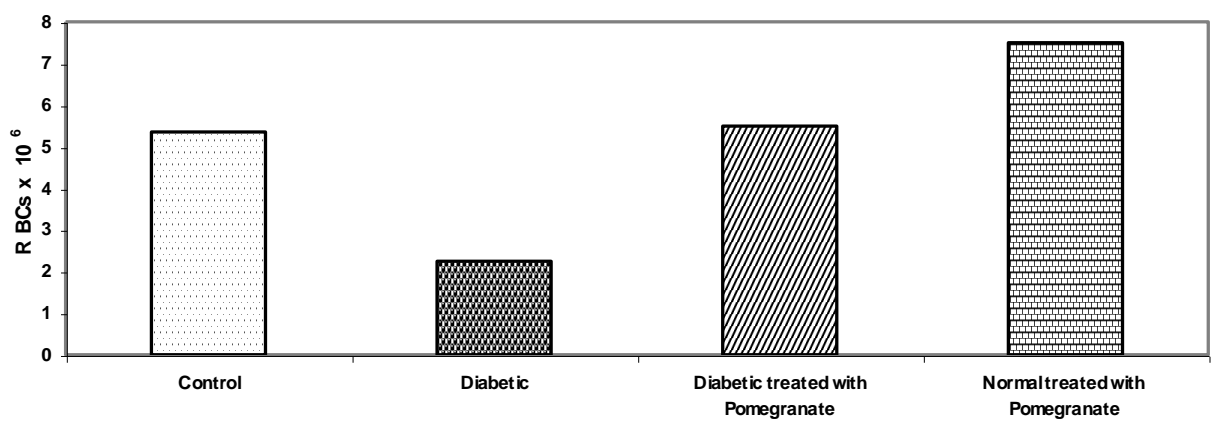

Fig 3: Showing the effect of treatment with $0.43 \mathrm{~g} / \mathrm{kgBW}$ Pomegranate(Punica granatum) peel aqueous extract for 4 weeks in W B Csx $10^{3}$ in normal and diabetic rats

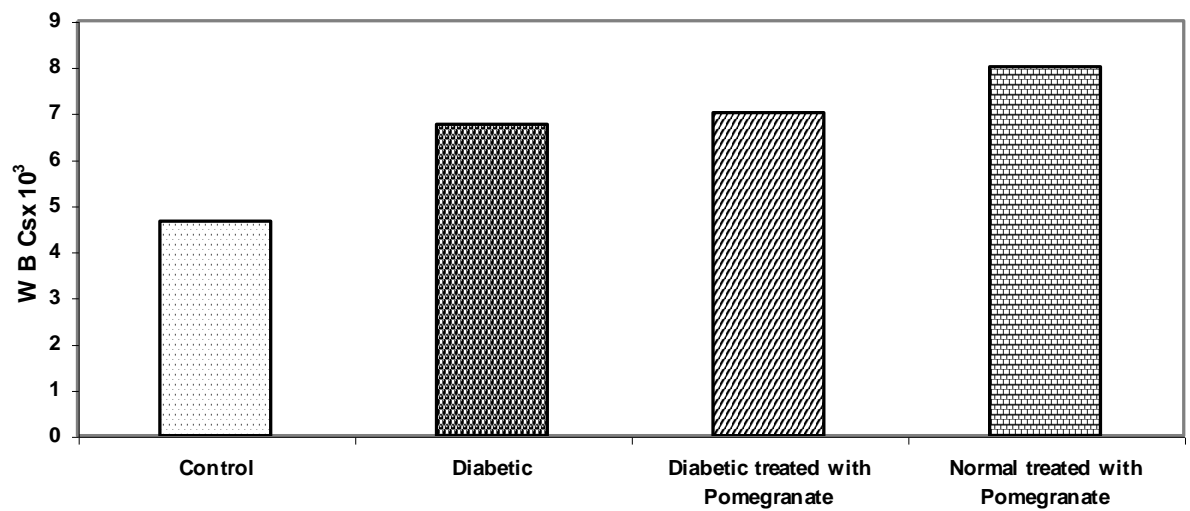

Fig 4: Showing the effect of treatment with $0.43 \mathrm{~g} / \mathrm{kgBW}$ Pomegranate (Punica granatum) peel aqueous extract for 4 weeks in $\mathrm{Hb}$ (gm \%) in normal and diabetic rats

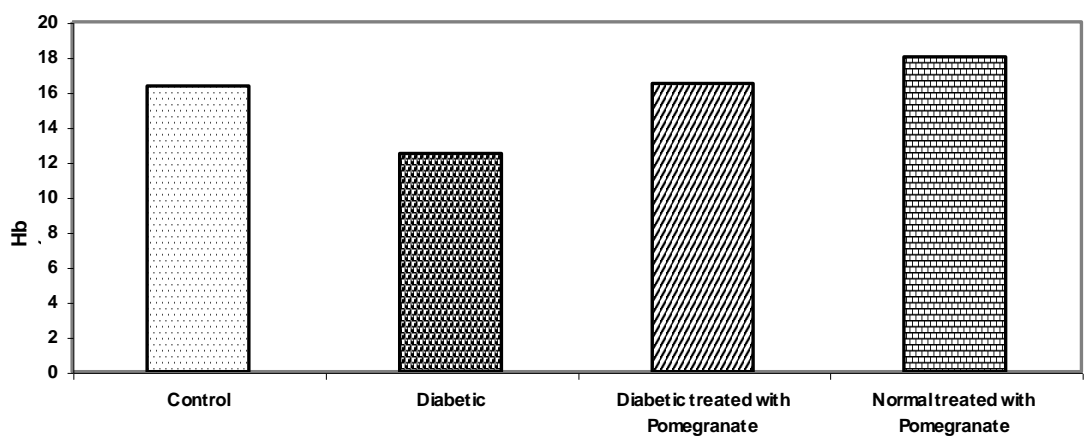


Fig 5: Showing the effect of treatment witto.43g/kgBW Pomegranate(Punica granatum) peel aqueous extract for 4 weeks in Glucos $(\mathrm{mg} / \mathrm{dl}$ ) in normal and diabetic rats

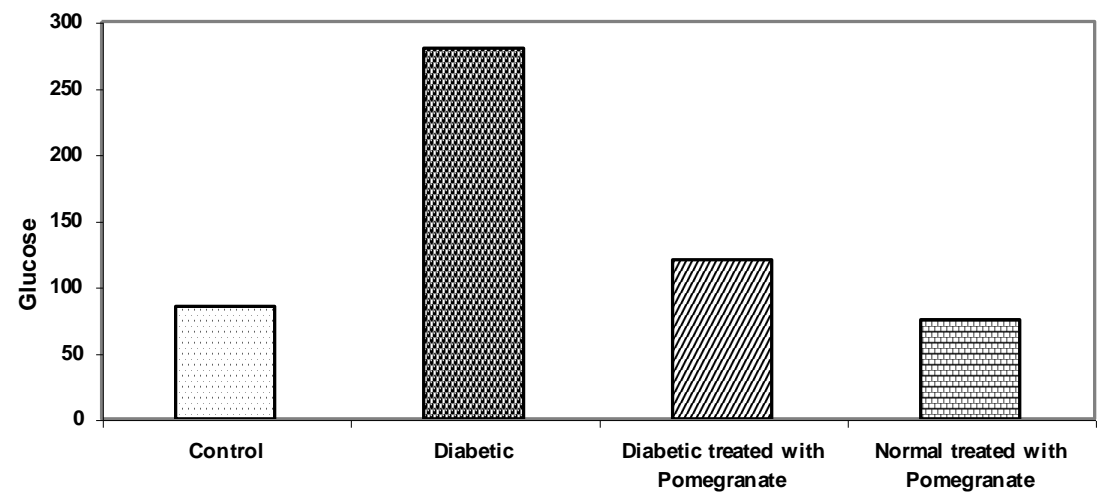

Fig 6: Showing the effect of treatment wita $43 \mathrm{~g} / \mathrm{kgBW}$ Pomegranat@Punica granatum peel aqueous extract for 4 weeks in In suli $(\mu \mathrm{U} / \mathrm{ml})$ in normal and diabetic rats

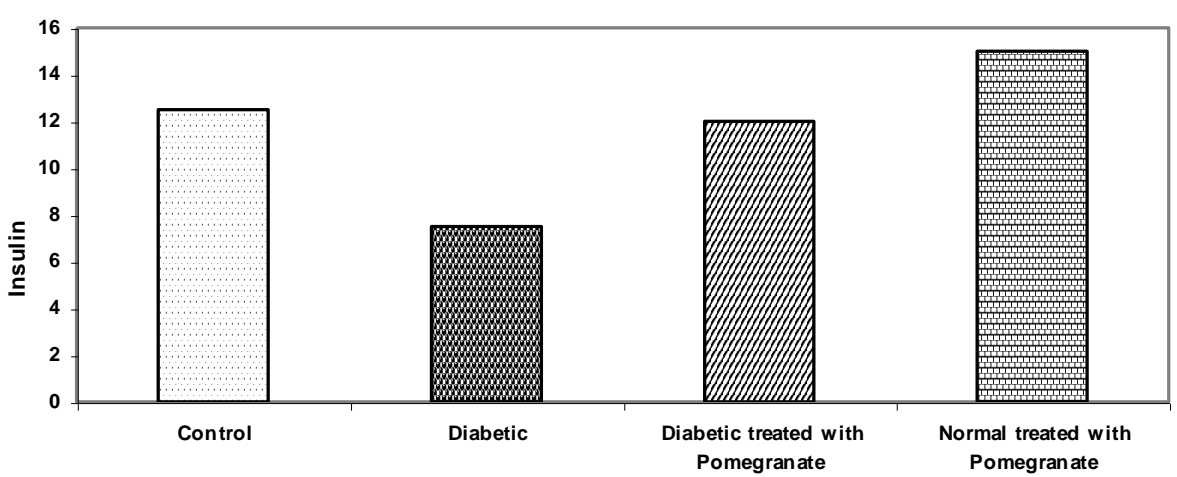

\section{Legend of figure}

Fig.7: Control rat pancreas showing islet of langerhans containing $\alpha, \beta$, and $\delta$ cells. $\beta$ Cells are the most abundant cells. $\quad$ M. A.F. $x 400$.

Fig.7a: Control rat pancreas

M. A.F. x 1000.

Fig.8: Diabetic rat pancreas showing, reduction in the pancreatic $\beta$ cell numbers, $B$ cell vacuolization and necrosis in some surviving $B$ cells M.A.F. $x 400$.

Fig.8a: Diabetic rat pancreas M.A.F. x1000

Fig 9: Pancreas of normal rats treated with Punica granatum peel extract showing regeneration of $B$ cells M. A.F. x 400 .
Fig.9a: Pancreas of normal rats treated with Punica granatum peel extract

M.A.F. $x 1000$

Fig. 10: Pancreas of diabetic rats treated with Punica granatum peel extract showing regeneration of $B$ cells ,while vacuolation still appeared in some cells

M.A.F. x400

Fig.10a: Pancreas of diabetic rats treated with Punica granatum peel extract M.A.F. x1000 


\section{Enas A. M. Khalil}
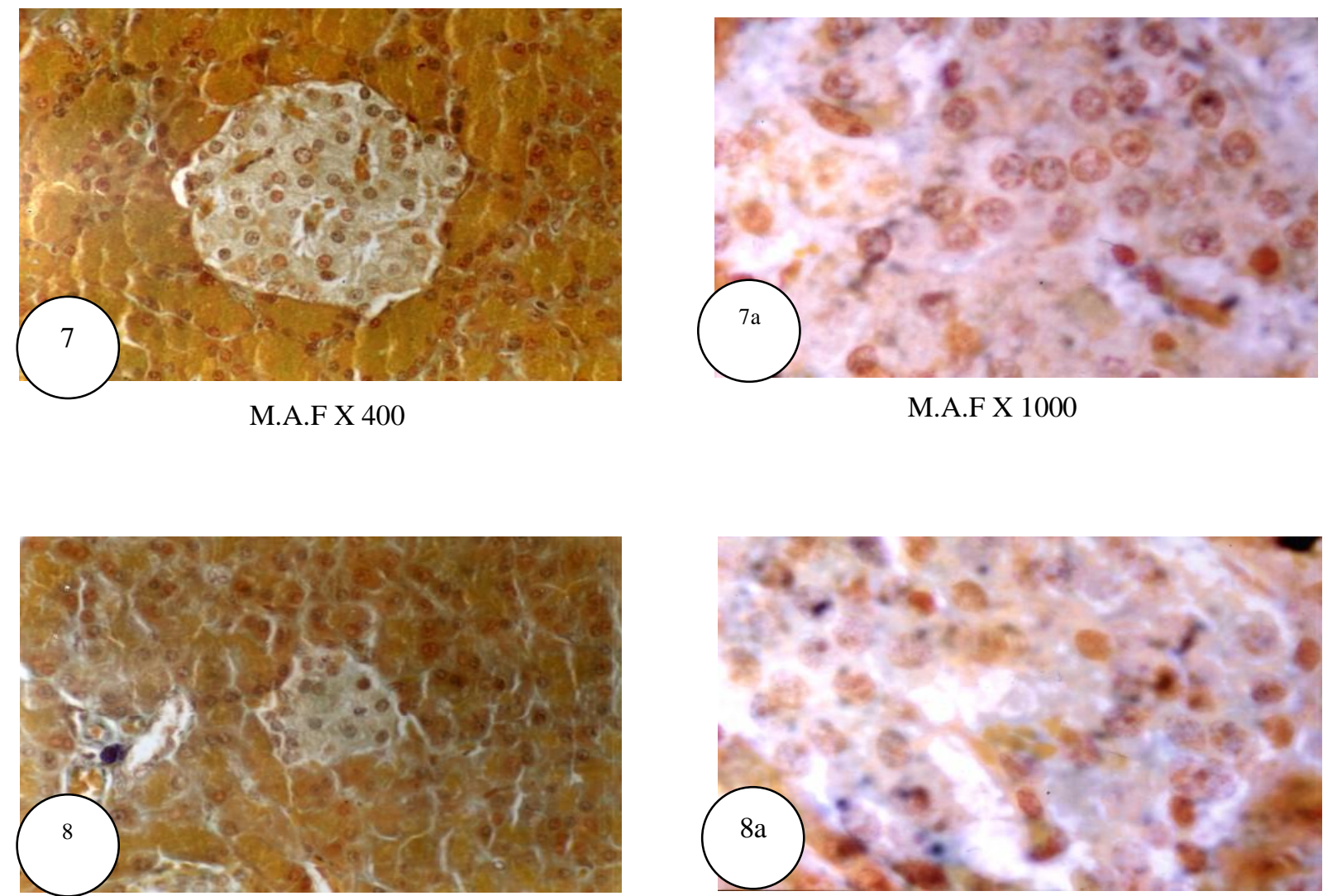

M.A.F X 400

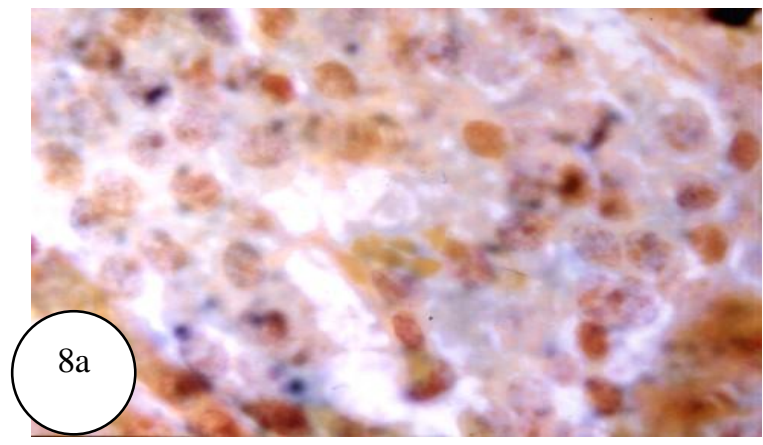

M.A.F X 1000

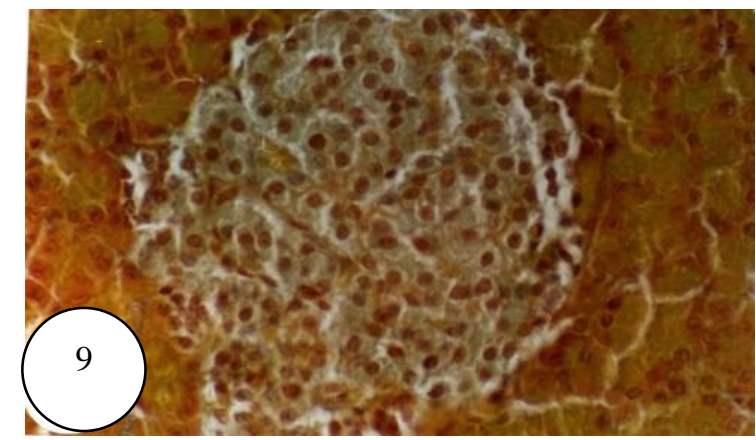

M.A.F X 400
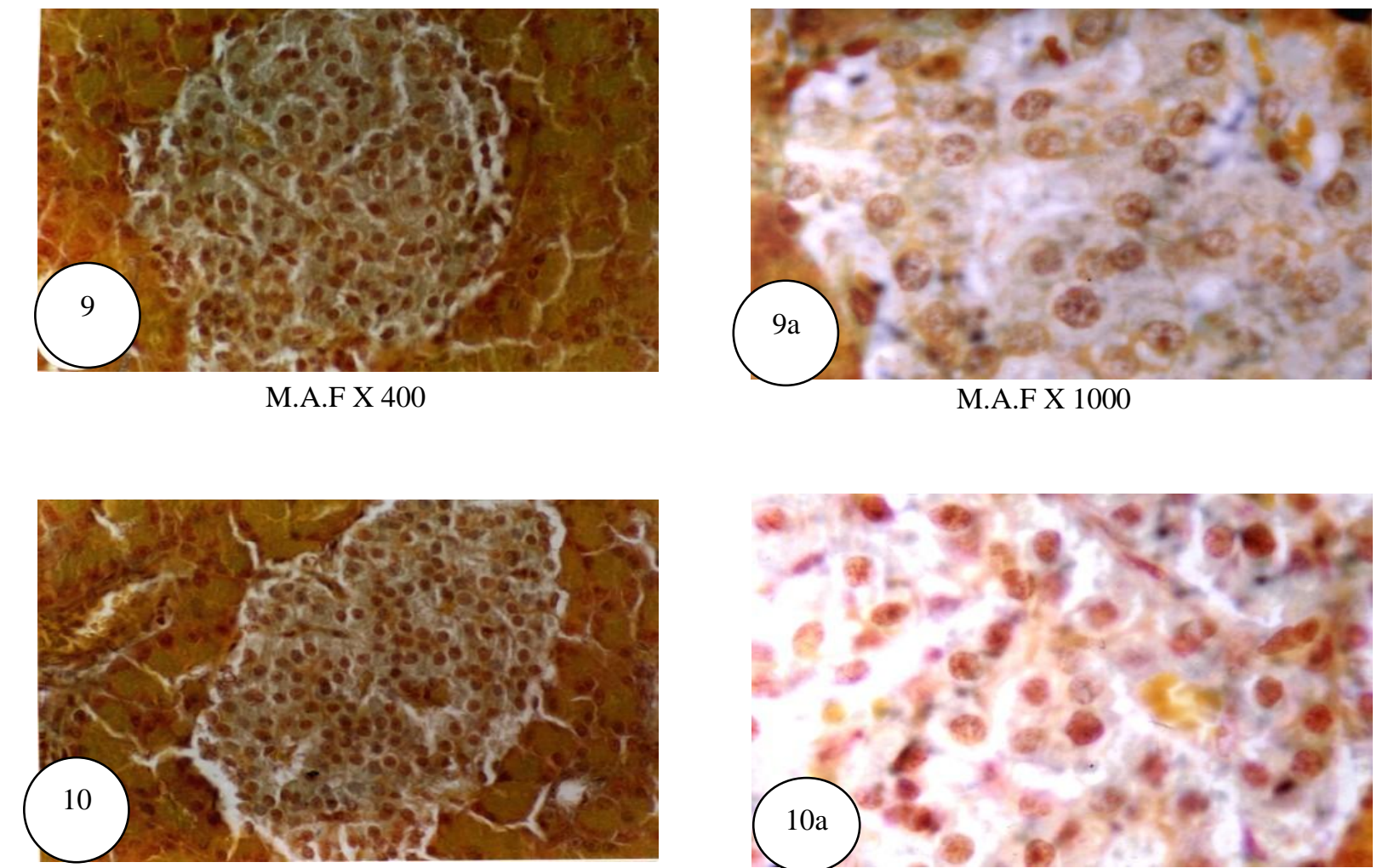

M.A.F X 400

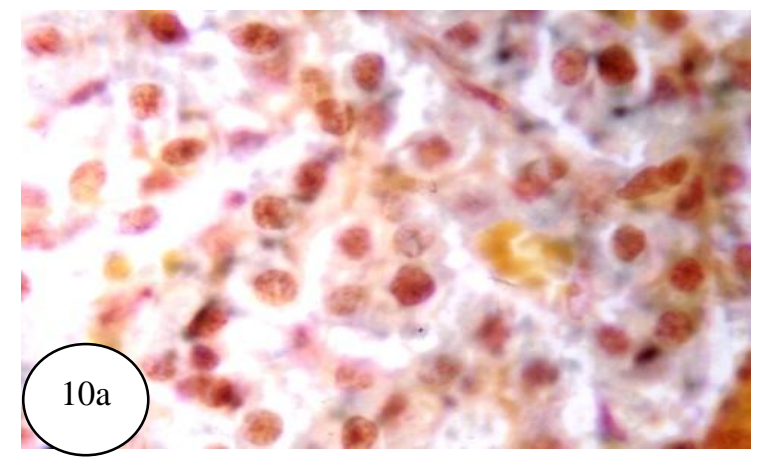

M.A.F X 1000 


\section{References}

1. Chidambara,M. K. ; Jayaprakasha, G.K.and Singh R.P.(2002):Studies on antioxidant activity of pomegranate (Punica granatum) peel extract using in vivo models .J. Agric Food Chem 14;50(!7) : 4791

2. Chidambara,M. K. ;Reddy ,V.K.; Veigas, J.M. and Murthy,U.D. (2004): Study on wound healing activity of Punica granatum peel .J. Med.;7(2):256

3. Dutta, B.k.; Rahman,I and Das,T.K.(1998) :Antifungal activity of Indian plant extracts. Mycoses ;41(11-12) 535

4. Gharzouli, K, Khennouf ,S ,Amira S., Gharzouli,A (1999): Effects of aqueous Extracts from quercus ilex L. root bark , Punica granatum 1.fruit peel and Artemisia herba asso leaves on ethanol -induced gastric damage in rats. Phytother Res;13 (1): 42

5. Goth, M. D. (1985): Medical Pharmacology, $9^{\text {th }}$ Ed. Mosby. Saint Louis p.471. In contrast to the oral antidiabetic agents, the exogenous administration of insulin is well known to produce hypoglycaemia in both normal and alloxan induced subjects.

6. Gracious,R.R.,Selvasubramanian,S. and Jayasundar S. (2001): Immunomodulatory activity of Punica granatum in rabbits -a preliminary study.J. Ethnopharma , 78, , 1, 85

7. Hallwell,B and Gutteridge,J.(1985):Free radical in biology and medicine.P.215

8. Kiernan,J.A. (1999): Histological and histochemical Methods. Theory and Practice $3^{\text {rd }}$ ed P.161.Printed in Great Britain by the both Press, Somerest.

9. Larner,J.(1985): Insulin and oral hypocaemic drugs, Glucogon .In: Gilman, A.O. Goodman ,L, S.,Rall, T.W., Murad, f.(Eds.).The Pharmacological Basic of Therapeutics, $7{ }^{\text {th }}$ Ed. Macmillan, Newyork p. 1490

10. Machado, $\mathbf{T}$.B.;Leal,I.C.;Claudia,A. and Amaral,F.(2002): Antimicrobial Ellagitannin of Punica granatum fruits: J.Braz.Chem.Soc.V.13 No.5

11. Mavhjanav,S.M.;Islambekov,S.Y.;Karim dzhanav,A.L.Ismailov,A.L.(1997):Polyph enols of pomegranate peels show marked antitumoer and antiviral action Khim Prir Soedin, 33:124

12. Morsy, T.A.; Mazyad, S.A. and ElSharkawy(1998): The larvicidal activity of solvent extracts of three medicinal plants against third instar larvae of chrysomyia albiceps. J. Egypt Soc.Parasitol ; 28(3):699

13. Navarro, V. ; Villarreal, M .l. ; Rojas, G and Lozoya, X.(1996): Antimicrobial Evaluation of some plants used in Mexican traditional medicine for the treatment of infectious diseases .J. Ethnopharma.; 53 (3): 143

14. Nogueira,D.G.,Pereira,N.A.,(1984):Activi ty of Punica grantum L.extract in Hyperglycemic mice treated with propranolol. Rev. Bras. Farm.65,46

15. Nogueira,D.G.,Pereira,N.A.,(1986a):Effe ct of an alcoholic extract from the pericarp of roma (Punica grantum L.) on insulin hypoglycaemia mice. Rev. Bras. Farm.67,59

16. Nogueira,D.G.,Pereira,N.A.,(1986b):Inhi bitory action of intestinal absorption of glucose of the pericarp of roma (Punica grantum L.) Rev. Bras. Farm.67,129

17. Nozire ,O. and Serpil,D.(1993): Valuation of the pomegranate (Punica granatumL.) peels from the stand point of pharmacy .Ankara Ecz.Fak.Derg.,22(1-2),21

18. Paget, G. E. and Barnes, J.M.(1964):"In toxicity tests" Vol.(1). Chapter (6) P.135, Editor: Laurance, D.R. and A. L. Academic Press, London, New York.

19. Prashanth ,D.; Asha,M.K. and Amit, A.(2001): Antibacterial activity of Punica granatum . Fitoterapia;72(2):171

20. Sendecor, G.W. and Coebram, W.C.,(1969):In "statistical Methods "6 ${ }^{\text {th }}$ ed Iowa State Univ. Press Anes, Iowa, U. S.A. P.70

21. Trinder,P.(1969): Determination of glucose in blood using glucose oxidase with an alternative acceptor .Ann. of Clinc.Biochem.6,24

22. Van-Elswijk,D.A., Schobel, U.P. Lansky, E.p. Irth ,H.and Van-der- Greef ,G.(2004): Rapid dereplication of estrogen compounds in Punica granatum using online biochemical detection coupled to mass spectrometry. Phytochemistry;65(2):233

23. Zafar, R. and Singh, J.,(1990): Antidiabetic activity of Punica granatum Linn. Sci.Culture 56(7), 3.

24. Zhang, J.; Zhan, B., Yao,X. Gao,Y. and Shong J. (!995): Antiviral activity of tannin from the pericarp of Punica granatum L. against genital Herpes virus in vitro .Zhongguo Zhong Yao Za Zhi;20(9) 556. 
التأثير المعالج لمرض السكر بالمستخلص المائى لقشر الرمان فى الجرذان المصابه بمرض السكر المستحدث بالألوكزان

\author{
أيناس على مهدى خليل \\ الهيئة القوميه للرقابه والبحوث الدولئ
}

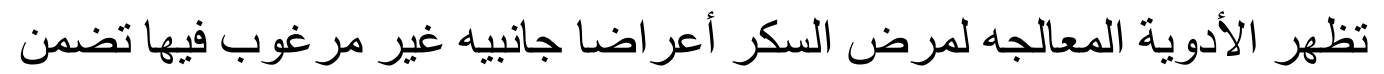

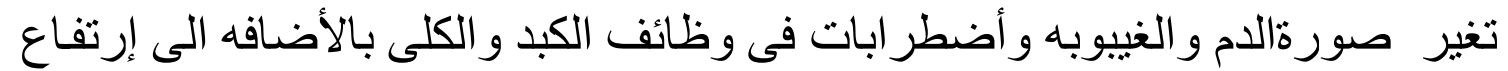

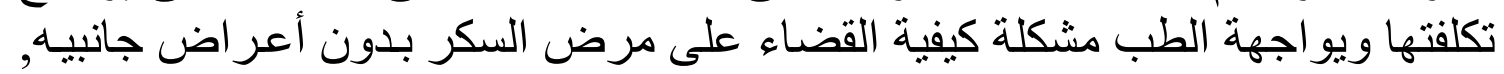

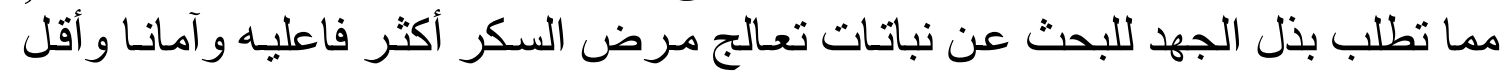
تكلفه

يهذف هذا البحث تقييم فاعلية الستخلص المائى لقشرة الرمان بجر عته العلاجيه

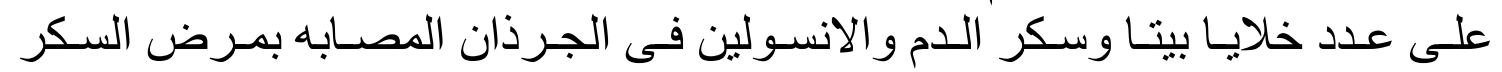
و أخرى غير المصابة لمدة أربعة أسابيع.

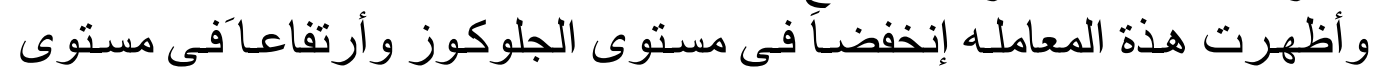

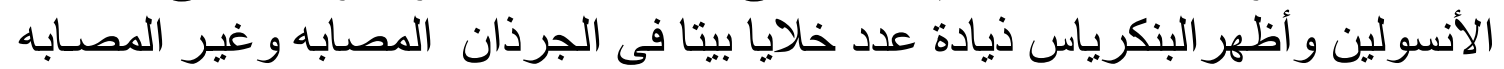

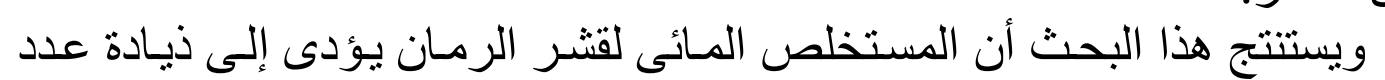
بمرض السكر.

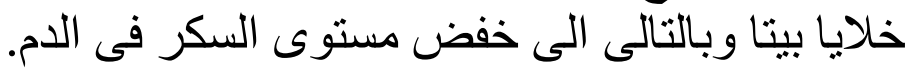

